\title{
Influencing the Bureaucracy: The Irony of Congressional Oversight
}

\author{
Joshua D. Clinton Vanderbilt University \\ David E. Lewis Vanderbilt University \\ Jennifer L. Selin Vanderbilt University
}

\begin{abstract}
Does the president or Congress have more influence over policymaking by the bureaucracy? Despite a wealth of theoretical guidance, progress on this important question has proven elusive due to competing theoretical predictions and severe difficulties in measuring agency influence and oversight. We use a survey of federal executives to assess political influence, congressional oversight, and the policy preferences of agencies, committees, and the president on a comparable scale. Analyzing variation in political influence across and within agencies reveals that Congress is less influential relative to the White House when more committees are involved. While increasing the number of involved committees may maximize the electoral benefits for members, it may also undercut the ability of Congress as an institution to collectively respond to the actions of the presidency or the bureaucracy.
\end{abstract}



he final report of the National Commission on Terrorist Attacks upon the United States urged that "Congress should create a single, principal point of oversight and review for homeland security.... [We] believe that Congress does have the obligation to choose one in the House and one in the Senate, and that this committee should be a permanent standing committee with a nonpartisan staff" $(2004,421)$. Despite this recommendation, Congress created a situation where 108 committees and subcommittees oversee the Department of Homeland Security. ${ }^{1}$ Many believe that this amount of oversight has prevented Congress from being able to effectively monitor or control the department. Testifying before Congress after the attacks at Fort Hood, 9/11 Commission Chairman Thomas Kean and Vice Chair- man Lee Hamilton argued that "enduring fractured and overlapping committee jurisdictions on both sides of the Hill have left Congressional oversight in an unsatisfactory state" (Kaniewski 2010, 73). Mann and Ornstein (2006) similarly refer to the lack of oversight as "crushing," and the New York Times opines that the oversight is "a comedy that invites a fresh national tragedy." ${ }^{2}$ Critics lodge these charges despite-or perhaps because - so many committees and subcommittees exercise jurisdiction over the department. This example underscores how the internal organization of Congress might affect whether Congress or the president exercises more influence over agency policymaking.

The question of political control over the bureaucracy has a lengthy history because of the administrative

Joshua D. Clinton is Associate Professor of Political Science, Vanderbilt University, and Co-Director of the Center for the Study of Democratic Institutions, Department of Political Science, Vanderbilt University, PMB 505, 230 Appleton Place, Nashville, TN $37203-$ 5721 (josh.clinton@vanderbilt.edu). David E. Lewis is William R. Kenan, Jr. Professor of Political Science, Vanderbilt University, and Co-Director of the Center for the Study of Democratic Institutions, Vanderbilt University, PMB 505, 230 Appleton Place, Nashville, TN 37203-5721 (david.e.lewis@vanderbilt.edu). Jennifer L. Selin is a Ph.D. candidate in Political Science, Vanderbilt University and the Center for the Study of Democratic Institutions, Vanderbilt University, PMB 505, 230 Appleton Place, Nashville, TN $37203-5721$ (jennifer.l.selin@vanderbilt.edu).

This research was supported by the Woodrow Wilson School of Public and International Affairs at Princeton University. Prior versions of the article were presented at the 2011 annual meeting of the Southern Political Science Association, New Orleans, LA, and the 2011 Emory Conference on Institutions and Law Making. We thank Larry Evans, John Geer, Tom Hammond, Armando Razo, Bert Rockman, Craig Volden, and seminar audiences at the University of California, Berkeley, the University of Indiana, the University of Pennsylvania, and Texas A\&M University for helpful comments. All supplementary materials are available online at the AJPS Dataverse or http://www.vanderbilt.edu/csdi/research/data.php.

${ }^{1}$ See “Who Oversees Homeland Security? Um, Who Doesn't?” National Public Radio, July 10, 2010, http://www.npr.org/templates/story/ story.php?storyId=128642876 (accessed January 31, 2011).

${ }^{2}$ See, e.g., "Wayward Eye on the Homeland," New York Times, December 20, 2008, A26.

American Journal of Political Science, Vol. 00, No. 0, xxxx 2013, Pp. 1-15

(c) 2013, Midwest Political Science Association

DOI: 10.1111/ajps.12066 
state's critical role in policymaking. If unelected administrators make policy, they should arguably do so at the behest of democratically elected officials such as members of Congress or the president. Difficulties emerge because both Congress and the president have a constitutional claim over the actions of the bureaucracy, and the two branches often compete for control. This situation begs the question: to whom are bureaucracies more responsive? Further, how does the internal organization of Congress shape congressional influence over the bureaucracy? There is no shortage of predictions about the possible effects of increased committee involvement. Scholars have argued that more committees with overlapping jurisdictions and interests in agency policy may increase (e.g., Aberbach 1990; Bendor 1985; King 1997; O’Connell 2006) or decrease (e.g., Dodd and Schott 1979; Gailmard 2009; Hammond and Knott 1996, 1999; Miller and Hammond 1990) the relative influence of Congress over the bureaucracy.

Unfortunately, difficulties in measuring key relationships and the notion of policy influence detailed in the many existing theoretical predictions have limited scientific progress. We advance the literature in important ways by surveying nearly 2,000 federal executives responsible for implementing agency policy in 128 different agencies and bureaus during the $110^{\text {th }}$ Congress (2007-2009). Scholars have conducted important surveys of federal executives in the past (e.g., Aberbach and Rockman 2000; Golden 2000; Maranto 1993a, 1993b, 2005; Maranto and Hult 2004; Meier and Nigro 1976), but such work does not examine relative congressional and presidential influence, and it typically focuses on a limited number of agencies or executives.

We explore whether the institutional structure of Congress and a system of bureaucratic oversight that relies on multiple committees with overlapping jurisdiction tends to increase or decrease the ability of Congress to control the bureaucracy when faced with a president from the opposing party. We find that when more committees are involved in monitoring and potentially directing agency policymaking, Congress is less influential than the president for determining agency policy. Increasing the number of involved committees may maximize the electoral benefits for members and provide a platform for making public proclamations on issues of importance (Fiorina 1977; Mayhew 1974), but it also appears to undercut the ability of Congress to respond collectively to the actions of the presidency or the bureaucracy. Our results provocatively suggest that an institutional arrangement that may be electorally beneficial for individual members may not be optimal for Congress as a whole (Mayhew 1974).

\section{The Nature of Congressional and Presidential Influence}

Members of Congress seek to organize Congress so that they are able to provide input on issues of potential reelection importance (e.g., Dodd and Schott 1979; Evans 2005; Fenno 1973; Fiorina 1977; Hall 1996; Mayhew 1974; Shepsle 1978). The desire for members to be involved in important policy debates, however, can create ambiguous and overlapping committee jurisdictions because multiple committees are often interested in the same actions of the bureaucracy (cf. Baumgartner and Jones 1993; Dodd and Schott 1979; Evans 1999; King 1997; Seidman 1998; Talbert, Jones, and Baumgartner 1995). In fact, at least four committees oversee every agency-an authorizing and an appropriations committee from each chamber-and the number appears to be increasing over time (Baumgartner, Jones, and MacLeod 2000).

Scholars take different perspectives on whether an increase in the number of committees increases or decreases the influence of Congress on agency policies. Some scholars argue that increasing the number of involved committees increases congressional influence over agency policy if committees focus on different types of oversight, examine distinct aspects of agency performance, maintain committee-specific information networks, or coordinate their efforts (see Aberbach 1990). The redundancy resulting from having a standing committee system in each chamber may promote the discovery of more effective ways of doing things or lead to the detection of agency malfeasance, specifically if the committees are independent and not working at cross-purposes (see Bendor 1985; King 1997; Landau 1969; O'Connell 2006). The ability of committees to act unilaterally using advice and consent, investigatory, and appropriations powers may also increase congressional influence (e.g., Adler 2002; Arnold 1980; Banks and Weingast 1992; Fiorina 1977) if congressional demands overwhelm the ability of the agency to resist congressional influence.

Others, however, argue that increasing the number of committees may decrease congressional influence relative to the chief executive due to the increased transaction costs resulting from the increased time and resources needed to influence agency behavior through practices such as information gathering and dissemination, coalition building, and vote buying (Dodd and Schott 1979; Gailmard 2009; Hammond and Knott 1996; Miller and Hammond 1990). When presidents act unilaterally to influence agency policy through appointments, budget proposals, regulation, or other actions, Congress usually must coordinate a collective response. There are often many 
acceptable courses of legislative action-e.g., a new piece of legislation, an appropriations rider, or a threat to retaliate against the executive by another mean such as holding up one of the president's priorities - and it takes time, effort, and resources to coordinate and pursue a response (Cohen, Cuellar, and Weingast 2006; Ogul and Rockman 1990). Moreover, some committees may exert something akin to veto authority over legislative activity in particular policy areas (e.g., Hammond and Knott 1996; Miller and Hammond 1990; Moe 1984, 1987; Seidman 1998).

Influencing agency policy may be especially difficult if congressional actors disagree on what they want an agency to do (e.g., Balla 2000; Bawn 1995; Dahl and Lindblom 1953; Hall and Miler 2008; Woolley 1993). If increasing the number of involved committees increases the chances of congressional disagreement, congressional interests may be disadvantaged relative to a president who can speak with a single voice (e.g., Ferejohn and Shipan 1990; King 1997; Steunenberg 1992; Whitford 2005; Wood and Waterman 1993). As Congress tries to reconcile differences between chambers and among committees, the president may have an opportunity to exert influence (Moe 1984, 1985, 1987), or else agencies may protect themselves by aligning with those in Congress who share the agencies' preferences (Hammond and Knott 1996; Wilson 1989).

Even if committees can agree to a course of action, they may not have enough incentive to respond. Because committees have scarce resources in time, effort, and staff to commit to influencing agency policymaking, they may be less willing to respond when others are involved. The incentive to free ride typically increases as the number of committees increases (Gailmard 2009; Laffont and Tirole 1993), and this may affect Congress's ability to influence agency policy.

A third perspective on the question of whether increased committee involvement affects congressional influence over agency policy relative to the president is that perhaps there is no relationship because of the coordinating presence of the majority party. The Speaker of the House, for example, can determine the primary jurisdiction for new legislation and set deadlines for the delivery of legislation involving multiple committees (Evans 2005), and many argue that political parties are an important part of congressional decision making because they help overcome similar problems in lawmaking (cf. Aldrich 1995). The resources of the majority party may therefore help protect congressional interests and prevent a multitude of involved committees from undermining congressional influence relative to the president.

In short, there is an abundance of conflicting predictions regarding how increasing the number of involved committees may or may not affect the ability of Congress to influence agency policy, and a robust literature theorizes about the possible mechanisms of influence. We focus our attention on characterizing the empirical relationship and determining whether a greater number of committees appears to lead to more influence (perhaps because of the ability of committees to act unilaterally), less influence (perhaps because of increased transaction costs or more actors with an implicit veto), or whether there is no effect on congressional influence (perhaps because of the ability of political parties to coordinate congressional activity).

\section{Measuring the Relationship}

Despite well-formulated theories of congressional and presidential influence over the bureaucracy, empirically assessing the relationship is exceptionally difficult. One notable difficulty is that observable congressional activity may occur most when Congress has failed to effectively direct agency policy (Aberbach 1990; McCubbins and Schwartz 1984). If so, interpreting the effect of observable congressional oversight activity is difficult because it may indicate a lack of influence.

The indeterminacy between observable oversight activities and influence over agency policy has led scholars to look beyond congressional activity to characterize congressional influence (e.g., Miller 2005). Examining whether changes in agency outputs correlate with changes in congressional preferences (e.g., Weingast 1984; Weingast and Moran 1983) is revealing, but it requires comparing the preferences of agencies and relevant political actors, and it is limited to only those agencies with comparable and measurable outputs (e.g., Bertelli and Grose 2009; Scholz and Wood 1998; Snyder and Weingast 2000). It is also difficult to explore how the committee system affects congressional influence (e.g., Calvert, McCubbins, and Weingast 1989; MacDonald 2007; Wood and Anderson 1993; Whitford 2005).

A second obstacle to analyzing empirically the influence of Congress over agencies is to identify which congressional committees are relevant for agency and program oversight. Expanding, ambiguous, and overlapping committee jurisdictions mean that multiple committees are potentially interested in the same agencies (Aberbach 1990; Dodd and Schott 1979; King 1997). Congress itself has struggled to clearly describe committee jurisdictions. During the $103^{\text {rd }}$ Congress, for example, the Joint Committee on the Organization of Congress carried out three separate analyses of jurisdiction-a telephone survey of 
senior, career employees in the agencies' legislative offices; an examination of the hearing appearances of executive branch witnesses; and a review of patterns of multiple referrals in the House and Senate (U.S. Congress 1993). The fact that Congress itself lacks a clear idea of which committees oversee which agencies highlights the difficulty of measuring oversight and suggests a preliminary conclusion-if Congress itself does not even know which of its own committees are responsible for overseeing the various executive agencies, it may have difficulty influencing agency policy.

We address these challenges using a survey of federal agency administrators and program managers designed to measure congressional and presidential influence over agency policymaking during 2007 and 2008. In so doing, we use a method that Congress itself has used to measure its own oversight of the bureaucracy. As a result, even if our survey-based measure is imperfect, those imperfections likely also affect the understanding that Congress has about its own relationship with executive agencies.

We attempted to survey every appointed and career federal executive responsible for administering or managing programs in the federal bureaucracy about their opinions and perspectives on political influence in their respective agencies and bureaus. ${ }^{3}$ Of the 6,690 potential respondents, 2,225 executives from 128 different agencies and bureaus provided at least a partial response, and the average agency contains 14 respondents (the overall response rate was 33\%). Given this sample, we are able to examine the relative amount of congressional and presidential influence over agency policymaking across the

\footnotetext{
${ }^{3}$ See the online appendix for more details about the survey. The survey targeted 6,690 federal administrators and program managers, of which 2,225 responded to the survey and 1,926 completed the entire survey. The response rate was higher among career professionals than appointees; e.g., Clinton et al. (2012) have responses from 259 political appointees, of which 102 are Senate confirmed (out of 550 policy-relevant Senate-confirmed appointees). Out of approximately 700, 131 appointed members of the Senior Executive Service responded; not every appointee in the SES was an administrator or program manager. Even so, there is no difference between appointees and careerists in their perceptions of the difference of influence between the White House and congressional committees. Political appointees do identify 0.17 more committees on average than career professionals. Unaccounted for, the fact that appointees report a larger number of committees but no difference in White House influence may lead us to slightly overestimate the influence of committees on the relative influence of the White House because of sample selection. When models are estimated with or without appointees or use other measures of the number of committees, however, the model estimates are similar. Because we control for either agency fixed effects or the percentage of political appointees in the agency, this helps control for the possibility that appointees are systematically more or less likely to report presidential influence than careerists.
}

entire federal bureaucracy in the $110^{\text {th }}$ Congress (20072009).

While important surveys of federal executives have been conducted previously (e.g., Aberbach and Rockman 2000; Golden 2000; Maranto 1993a, 1993b, 2005; Maranto and Hult 2004; Meier and Nigro 1976), they are of limited use for determining congressional and presidential influence over agency policy. Existing surveys interview fewer executives (the largest prior single survey contained 612 respondents) from fewer agencies (prior surveys included a maximum of 15 agencies), and they fail to ask about oversight and influence. ${ }^{4}$ The closest survey to our own is Golden's (2000) survey that focuses on the president's (but not Congress's) ability to direct policy within four agencies. ${ }^{5}$

Using the opinions and perceptions of administrators and program managers to measure the relative influence of the elected branches and the number of involved committees provides two important advantages. First, because the individuals surveyed are responsible for implementing agency policy, their perceptions are especially meaningful. Executives who believe that Congress is more influential, for example, likely take on the job actions that reflect and validate this belief. Second, by relying on the perceptions of those responsible for implementing agency policy, we can measure influence and interactions that are not observable or easily interpretable by those outside of the agency. If agencies react to the expectation of negative consequences that would result if the agency offended Congress, for example, it is possible that congressional committees influence agency policy without taking observable actions (McCubbins, Noll, and Weingast 1987, 1989; McCubbins and Schwartz 1984; Weingast and Moran 1983). If so, the opinions and perceptions of federal executives presumably reflect such influence, whereas relying on observable actions does not.

Despite these reasons for preferring our measure to existing measures, no measure is perfect. One concern with using survey responses to measure influence is that the political circumstances surrounding the survey-i.e.,

${ }^{4}$ For a closely related effort at the state level, see Hebert, Brudney, and Wright (1983), who survey American state administrators to evaluate gubernatorial influence over agency decisions.

${ }^{5}$ The other surveys focus on the dynamics between careerists and political appointees (Maranto 1993a, 1993b, 2005; Maranto and Hult 2004), representative democracy (Meier and Nigro 1976), and the alleged quiet and noisy crises in the civil service (Aberbach and Rockman 2000). Aberbach and Rockman (2000) use interviews conducted in 1970 (126 executives), 1986-87 (199 executives), and 1991-92 (151 executives) for a total of 476 executives, and Maranto and Hult (2004) and Maranto (2005) use a combination of two surveys (one each from 1987 and 1993) for a total of a little over 1,100 respondents. 
a Democratic Congress grappling with a Republican president in his second term - or personal biases of respondents may affect the meaning of the reported measures. To minimize this possibility, we use information about the respondents and the agencies in which they work to control for potential sources of bias when conducting the analysis. Controlling for the ideology and partisanship of the executive, for example, allows us to focus on the variation in the perceived relative influence that is unrelated to variation in personal characteristics or agency features. ${ }^{6}$ A related concern is that the executives who respond to our survey on the "future of government service" may be either the happiest or most despondent given the political circumstances. However, comparing the partisanship of respondents and nonrespondents using voterregistration data reveals no discernible differences (see online Appendix B for other comparisons of respondents and nonrespondents).

To measure influence over agency policymaking, we ask executives and program managers: "In general, how much influence do the following groups have over policy decisions in your agency?" We ask about "Democrats in Congress" (the majority party in the House and Senate in 2007-2009), "Congressional committees," the "White House," and "Interest Groups." Respondents answer these questions using a grid listing all of the groups being rated to prime them to think about the relative influence of the various political actors and prevent the possibility of forgetting earlier responses. Because individuals may use the scales differently, we difference the measure of congressional influence (i.e., either "Congressional Committees" or "Democrats in Congress") from the measure of White House influence for each respondent to produce an individual-level measure of relative influence that can range from -4 (total domination by Congress) to +4 (total domination by the White House).

To measure the number of congressional committees overseeing agency policymaking given the possibility of unobservable committee oversight (e.g., unpublished hearings, personal communications), we again rely on the bureaucrats" self-reports. We ask: "How many congressional committees would you estimate exercise active oversight of your agency? $(0 ; 1-2 ; 3-4 ; 5-6 ; 7-8 ; 9+) . ”$ The modal response was " $3-4$ " committees.

${ }^{6}$ Similarly, if appointees are selected because they share the president's preferences, we might worry that using self-reported measures of influence ignores the influence occurring because of staffing decisions instead of explicit directives. We therefore also use characteristics of the respondent and agency that are correlated with possible selection-based influence (e.g., excluding the opinions of political appointees because they would be most likely to underreport the influence of the appointing president due to selection issues).
Because every executive belongs to a cabinet department, administration, bureau, or commission, we aggregate the individual measures to characterize the average perception in an agency or a bureau. We classify respondents from large, distinct bureaus (e.g., FBI, Census) by bureau, and we identify executives from smaller offices or divisions (e.g., Office of the Secretary, Inspector General) that are located in larger departments with their larger department or agency. While this survey allows us to connect 128 different agencies to congressional committees with oversight jurisdiction, more than any previous survey, it still requires us to aggregate together employees working in bureaus or offices that can be quite different. Reassuringly for our purposes, the Department of Homeland Security (4.70) and the Environmental Protection Agency (4.13) have among the highest levels of perceived committee oversight, while the Veterans Benefits Administration (2.64) and the Bureau of Labor Statistics (2.4) have among the smallest.

The fact that the average response for the Department of Homeland Security indicates that seven to eight committees exercise active oversight may appear puzzling given that 108 committees and subcommittees had jurisdiction over the agency. Recall, however, that we only ask about committees, and we measure the average number of committees involved. If individuals within an agency interact with different committees, this average will underreport the number of unique committees involved. (The online appendix compares our measure of congressional oversight to other measures of congressional oversight.)

We begin by examining the bivariate relationship between the number of involved committees and relative influence. ${ }^{7}$ Figure 1 graphs the relationship between the number of committees overseeing the respondent's agency and the respondent's evaluation of the relative influence of the White House vis-à-vis Congress and the Democratic Party. Several patterns emerge. First, respondents always perceive congressional committees to be more influential than majority party Democrats in Congress-suggesting that any party influence occurs largely through the committee system. If federal executives work day to day with congressional staff, executives may perceive more influence from committees than party organs within Congress even if parties are influencing

\footnotetext{
${ }^{7}$ Although we cannot know for certain what is in the minds of respondents when completing the survey, our implicit assumption is that respondents make some assessment of the sum of committee influence when evaluating the influence of committees over policymaking. Respondents reporting that 0 committees conduct active oversight may still report substantial committee influence since policy decisions are made in the shadow of potential committee action.
} 


\section{FIGURE 1 Relationship between Relative White House Influence and Number of Committees Exercising Active Oversight}

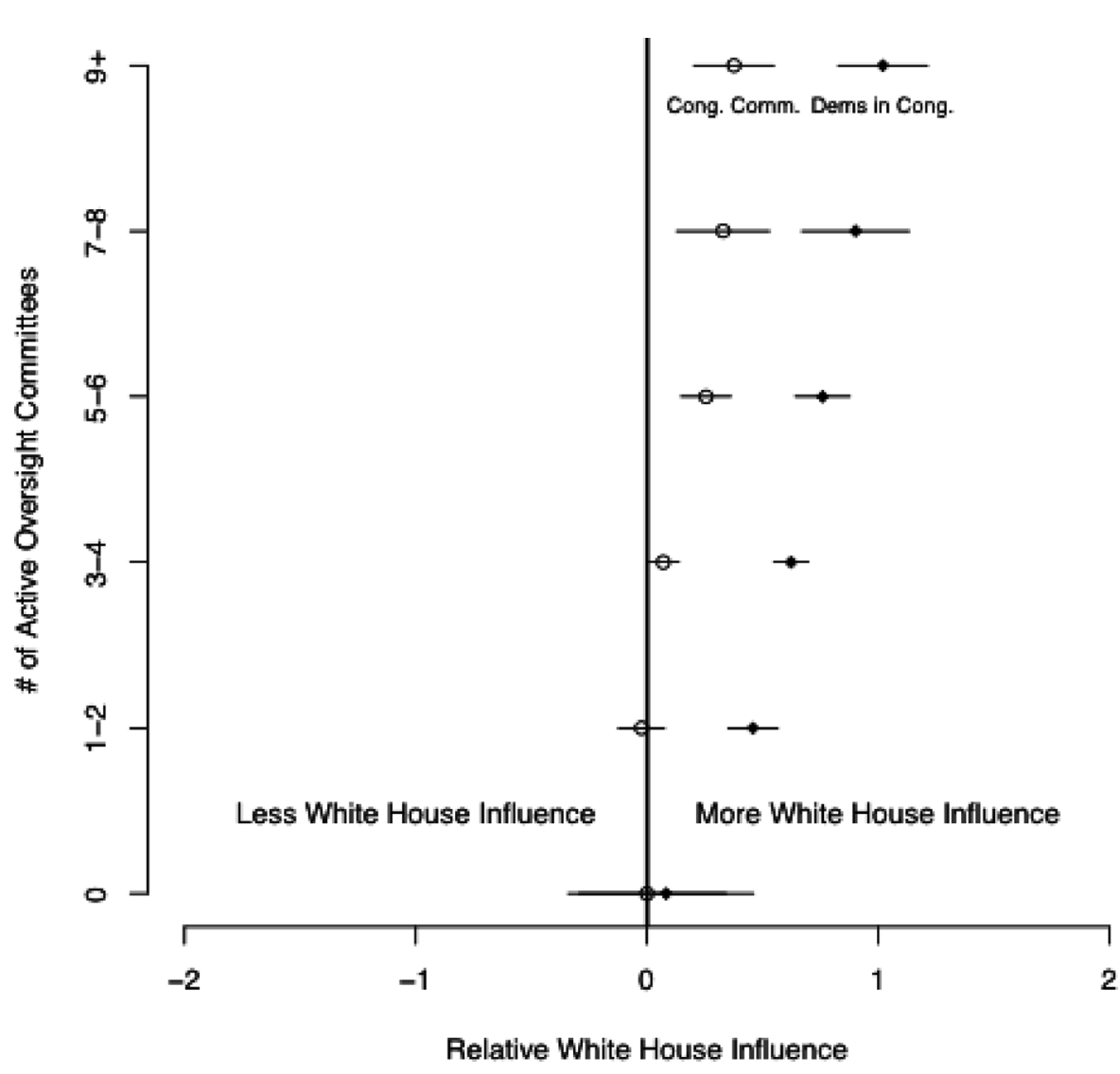

Note: Differences and 95\% confidence intervals relative to congressional committees (open) and Democrats in Congress (solid) are plotted.

the work of committees. Second, the relative influence of the White House increases in a nearly linear fashion as the number of committees exercising active oversight increases. Figure 1 also reassuringly suggests that executives do not simply equate oversight and influence. If they did, we would expect to find that bureaucrats report more congressional influence when the number of committees exercising active oversight increases. Because we observe the opposite relationship, even if bureaucrats mistakenly equate oversight and influence, this would only increase the disparity in the amount of influence that we document.

\section{Estimating the Relative Influence of the President and Congress over Agency Policy}

Figure 1 suggests that Congress is less influential than the president when more committees are involved, but there are obviously many possible rival explanations and confounding characteristics that need to be explored before we can characterize the relationship with any confidence. We first explore how the relationship varies across agencies before turning to exploring the variation evident in the individual-level experiences of career executives. ${ }^{8}$

Several alternative explanations may explain why increased committee involvement results in less congressional influence relative to the president. One possibility is that the number of tasks an agency performs may produce the noted correlation; agencies handling many tasks across multiple issues may both be more likely to cross the jurisdictions of multiple committees and be harder for Congress to control because of the agency's

\footnotetext{
${ }^{8}$ Section A6 in the online appendix shows that the relationship is also unchanged if we use interest-group influence as a proxy for congressional influence as might be expected if Congress relies on interest groups to influence agency policy; Section A4 in the online appendix replicates the analysis that follows to show that examining the influence of the majority party in Congress does not affect the results.
} 
specialized information and expertise. If so, a negative relationship between the number of involved committees and relative congressional influence would occur because of the number of tasks rather than the number of involved committees. We use multiple measures to control for this possibility, but the results that follow use the number of distinct Policy Areas in which the agency is involved according to budgetary documents. ${ }^{9}$

A second alternative explanation for the relationship between the number of committees and relative presidential influence is due to the salience of an agency's work to the president's agenda. If the president prioritizes some agencies and programs over others, and those agencies consequently report higher levels of presidential influence because of the increased presidential attention, then the observed relationship would be spurious if the importance of the agency for the president's agenda correlates with the number of committees involved (perhaps because members of Congress want to appear responsive on the same issues). To measure which agencies are important for achieving the policy goals of President Bush during the $110^{\text {th }}$ Congress, we create an indicator variable (Bush Agenda?) using the 2007 State of the Union Speech and a 2006 evaluation of his agenda by the New York Times (Fishel 1985) to identify the agencies that implemented policies important to President Bush.

We also control for characteristics that may affect respondents' perceptions of influence and oversight. If liberal executives, or members of more liberal agencies, are more sensitive to attempted influence by the Republican president than the Democratic Congress because of their ideological disposition, then the disparity in influence we document may be illusory. We therefore control for the ideology of the agency (Agency Preferences) using experts' assessments (Clinton and Lewis 2008) to account for the possibility that an agency's ideology either affects the actual receptiveness of the agency to congressional or presidential influence or else the perceptions of executives and program managers within the agency.

To account for possible variation in political influence across different types of agencies, we include indi-

\footnotetext{
${ }^{9}$ As part of budget preparations during the Bush administration, the Office of Management and Budget categorized federal programs into 17 policy areas (programs could have more than one category). For each agency, we counted the number of different policy areas covered by the agency's programs. Auxiliary analyses reveal that our conclusions are robust to using a host of alternative measures of agency tasks, including the number of distinct bureaus within an agency and the proportion of an agency's programs that are in one policy area. The relationship between the number of policy areas in which an agency is involved and the number of committees perceived to be actively overseeing the agency is very weak (correlation of 0.17 ).
}

cators for agencies that are located within independent commissions (Independent Commission?) and cabinet departments (Cabinet Department?). Because the proximity of career executives to Washington, DC, may also affect how responsive the executives perceive congressional and presidential influence, we control for the percentage of respondents in the agency who are located in a field office outside of Washington, DC (\% Field Office). Finally, because presidents may exercise influence through the appointment process, and appointees may be less likely to perceive presidential influence, we also control for the percentage of respondents who are political appointees (\% Political Appointee).

Using the agency-level variation and controlling for possible rival and confounding effects, Table 1 reveals that the president is more influential relative to Congress the more congressional committees there are that are involved in overseeing an agency or a bureau. Model 1 suggests that increasing the average number of committees overseeing an agency from " 1 to 2 " to " 3 to 4 ," for example, increases the president's relative policy influence by 0.22 , which is nearly one-third of a standard deviation. The difference in relative presidential influence for an agency with no committee oversight compared to an agency with "9+" committees is equivalent to going from a world where, for example, a respondent suggests the two branches both exert "A good bit" of influence to one where the respondent reports that the president still exerts "A good bit" of influence but Congress exerts only "some" influence. Excluding the opinions of political appointees does not change the results (Model 2).

Model 3 reveals that party institutions do not exercise much independent influence. The fact that President Bush's influence relative to the Democratic Party controlling the House and Senate is correlated with the number of committees involved suggests that the majority party does not solve the problems that result from the involvement of multiple congressional committees, at least in the context of the $110^{\text {th }}$ Congress. This raises the important question of whether legislatures in other contexts with stronger parties can overcome the effects of a proliferation of committees on agency oversight.

The other included covariates have reasonable effects. Agency salience and work complexity do not affect the relative influence of presidents, but other factors do. As more of an agency's executives are located in field offices, the relative influence of the president decreasespresumably because of the local influence wielded by the members of Congress in whose district the offices are located. Similarly, independent commissions report far more influence by Congress. Finally, the negative correlation between agency ideology and relative presidential 


\section{TABLE 1 Agency-Level Regression Results for the Effect of Multiple Committee Oversight on} Influence

\begin{tabular}{|c|c|c|c|c|}
\hline & $\begin{array}{l}\text { White House } \\
\text { Influence Relative } \\
\text { to Congressional } \\
\text { Committees: } \\
\text { All Executives } \\
\text { (Model 1) }\end{array}$ & $\begin{array}{l}\text { White House } \\
\text { Influence Relative } \\
\text { to Congressional } \\
\text { Committees: } \\
\text { Careerists Only } \\
\text { (Model 2) }\end{array}$ & $\begin{array}{l}\text { White House } \\
\text { Influence } \\
\text { Relative to } \\
\text { Democratic Party: } \\
\text { All Executives } \\
\text { (Model 3) }\end{array}$ & $\begin{array}{l}\text { White House } \\
\text { Influence } \\
\text { Relative to } \\
\text { Democratic Party: } \\
\text { Careerists Only } \\
\text { (Model 4) }\end{array}$ \\
\hline Constant & -.39 & -.43 & .11 & .26 \\
\hline (Standard error) & $(.36)$ & $(.33)$ & $(.35)$ & $(.36)$ \\
\hline Avg. \# of Oversight Committees & $\begin{array}{c}.22^{*} \\
(.11)\end{array}$ & $\begin{array}{c}.25^{*} \\
(.10)\end{array}$ & $\begin{array}{c}.22^{*} \\
(.10)\end{array}$ & $\begin{array}{c}.20^{*} \\
(.09)\end{array}$ \\
\hline \# Policy Areas for Agency & $\begin{array}{c}.01 \\
(.01)\end{array}$ & $\begin{array}{c}.01 \\
(.01)\end{array}$ & $\begin{array}{c}.02 \\
(.02)\end{array}$ & $\begin{array}{l}.02 \\
(.02)\end{array}$ \\
\hline Bush Agenda? & $\begin{array}{c}-.05 \\
(.09)\end{array}$ & $\begin{array}{c}-.01 \\
(.10)\end{array}$ & $\begin{array}{r}-.07 \\
(.10)\end{array}$ & $\begin{array}{c}-.08 \\
(.11)\end{array}$ \\
\hline Agency Ideal Point & $\begin{array}{r}-.14^{*} \\
(.04)\end{array}$ & $\begin{array}{r}-.15^{*} \\
(.04)\end{array}$ & $\begin{array}{r}-.11^{*} \\
(.05)\end{array}$ & $\begin{array}{r}-.10^{*} \\
(.05)\end{array}$ \\
\hline Independent Commission? & $\begin{array}{r}-.78^{*} \\
(.16)\end{array}$ & $\begin{array}{c}-.99^{*} \\
(.21)\end{array}$ & $\begin{array}{r}-.72^{*} \\
(.18)\end{array}$ & $\begin{array}{r}-.98^{*} \\
(.24)\end{array}$ \\
\hline Cabinet Department? & $\begin{array}{c}-.12 \\
(.13)\end{array}$ & $\begin{array}{c}-.19 \\
(.12)\end{array}$ & $\begin{array}{c}-.04 \\
(.15)\end{array}$ & $\begin{array}{c}-.14 \\
(.16)\end{array}$ \\
\hline$\%$ Political Appointees & $\begin{array}{l}.12 \\
(.37)\end{array}$ & & $\begin{array}{c}-.06 \\
(.34)\end{array}$ & \\
\hline \% Employed in Field Office & $\begin{array}{r}-.28^{*} \\
(.15)\end{array}$ & $\begin{array}{c}-.23 \\
(.16)\end{array}$ & $\begin{array}{r}-.56^{*} \\
(.20)\end{array}$ & $\begin{array}{r}-.55^{*} \\
(.22)\end{array}$ \\
\hline $\mathrm{R}^{2}$ & .39 & .43 & .39 & .39 \\
\hline $\mathrm{N}$ & 95 & 95 & 95 & 95 \\
\hline
\end{tabular}

Note: *denotes two-tailed significance at .10 or better.

influence suggests that respondents in the most liberal agencies report the most presidential influence relative to Congress. We cannot determine whether this is because presidents target such agencies for action or because such executives are most likely to perceive presidential influence, but the critical point to note is that our identification of the relationship between the number of committees involved in oversight and policy influence controls for either possibility.

\section{A Response Rather Than a Cause?}

Given the documented relationship between increased committee oversight and decreased congressional influence relative to the president, one might question whether the existence of multiple committee overseers is a cause of congressional weakness or a response to previous presidential influence. Put differently, is the negative relationship we document due to Congress reacting to prior presidential action? If so, more committee involvement may indicate more congressional influence relative to the president, and our interpretation would be backwards.

Because the House and Senate rules effectively fix the scope of committee oversight in the short term by defining committee jurisdictions, the proliferation of committees is more likely to be the cause of the lack of congressional control rather than a response. While committee jurisdictions do change over time (Baumgartner, Jones, and MacLeod 2000; King 1997), there is no evidence that the $110^{\text {th }}$ Congress changed congressional jurisdictions in response to presidential influence over agency policy.

To further explore the possibility of reverse causality, we examine whether the perceived number of committees that exercise active oversight varies with past presidential interest and influence in the agency. We estimate the number of committees conducting active oversight, controlling for whether the respondent approves of recent changes in the agency (Agree with Changes?), whether 


\section{Table 2 Predicting the Number of Committees Exercising Active Oversight}

\begin{tabular}{lc}
\hline & Coefficient \\
\hline Constant & $3.27^{*}$ \\
(Clustered standard error) & $.21)$ \\
Agree with Changes? & -.04 \\
& $(.03)$ \\
Aware of Burrowing? & -.08 \\
& $(.07)$ \\
Number of Political Appointees Increasing? & .02 \\
& $(.02)$ \\
White House Involvement Increasing? & -.05 \\
& $(.04)$ \\
\# Agency Policy Issue Areas & $.03^{*}$ \\
& $(.01)$ \\
Bush Agenda? & $.33^{*}$ \\
& $(.12)$ \\
$\mathrm{N}$ & 1486 \\
$\mathrm{R}^{2}$ & .05 \\
\hline
\end{tabular}

Note: ${ }^{*}$ denotes two-tailed significance at .10 or better.

political appointees have recently been "burrowing" into the career civil-servant positions in the agency (thereby presumably increasing presidential influence [Aware of Burrowing?], whether the number of appointees in the agency is increasing (Number of Political Appointees Increasing?), whether the executives report that the president is increasingly involved in agency activity (White House Involvement Increasing?), and whether the agency is responsible for the policy priority of President Bush (Bush Agenda?). If the number of committees exercising oversight is a consequence rather than a cause of increasing presidential control, we should expect at least some of these covariates to be related positively to the number of committees involved.

Table 2 reveals no reason to reject our interpretation of the relationship. Not only do the variables in Table 2 account for very little of the variation in the number of committees exercising active oversight, but also there is little evidence that increasing White House influence leads to increased levels of active committee oversight. Committees are not more involved in those agencies where White House influence is increasing; there are fewer committees involved in agencies where more burrowing by political appointees is occurring; and there is less committee oversight of agencies where changes objected to by the executive are taking place. There is a positive correlation between the number of committees involved in oversight and whether the agency is responsible for the policy pri- orities of President Bush, but we explicitly control for this possibility in earlier specifications.

\section{Program Manager and Executive-Level Analysis}

Agencies and bureaus are responsible for managing many different programs and policies, but the analysis of the third section cannot account for variation in the amount of oversight and influence within an agency. Federal executives who work in more political portions of the Defense Department such as the Joint Chiefs of Staff, Missile Defense Agency, or Comptroller likely have different experiences than those who work in less visible parts such as the Defense Logistics Agency or Networks and Information Integration. In fact, executives in the first group report an average of seven to eight committees compared to three to four committees for executives working in the second group. Exploring such variation in the opinions of the executives and program managers within an agency provides additional information about the nature of the relationship between the number of involved committees and congressional influence. ${ }^{10}$

Because executives and program managers work for a larger agency or bureau, running a regression on the pooled responses is inadvisable because of unaccounted for agency-level effects (that are therefore clearly not independent across respondents). For motivation, consider the simple univariate regression of executive i's opinions about the perceived relative influence of the president in agency $j\left(Y_{i j}\right)$ and the number of committees perceived to be exercising oversight in agency $j\left(X_{i j}\right)$ given by: $Y_{i j}=\beta_{0}+\beta_{1} X_{i j}+u_{j}+u_{i j}$. In addition to the typical idiosyncratic errors $u_{i j}$, there are also likely omitted effects correlated within an agency (denoted by $u_{j}$ ) because multiple executives and program managers belong to the same agency.

We estimate the relationship using a pooled ordinary least squares (OLS) model, an OLS model with agency fixed effects to allow the unknown agency-level effects $u_{j}$ to be correlated with the included covariates $X_{i j}$, and an ordered logit with agency fixed effects to explore whether treating the discrete response scale as continuous is consequential. (The online appendix reports the substantively identical results of a random-effects model, a multilevel model, and a Bayesian multilevel model.)

\footnotetext{
${ }^{10} \mathrm{We}$ interpret the variation in the responses of executives and program managers as reflecting the variation in their experiences when working to implement the various programs and policies of the agency.
} 


\section{TABLE 3 Executive-Level Regression Results for the Effect of Multiple Committee Oversight on White House Influence}

\begin{tabular}{|c|c|c|c|}
\hline $\begin{array}{l}\text { White House Influence Relative } \\
\text { to Congressional Committees }\end{array}$ & $\begin{array}{c}\text { OLS } \\
\text { (Model 5) }\end{array}$ & $\begin{array}{l}\text { OLS (Agency Fixed Effects) } \\
\text { (Model 6) }\end{array}$ & $\begin{array}{c}\text { Ordered Logit } \\
\text { (Agency Fixed Effects) } \\
(\text { Model 7) }\end{array}$ \\
\hline Constant & -.0002 & -.14 & -.20 \\
\hline (Standard error) & $(.13)$ & $(.11)$ & (.13) \\
\hline \# Oversight Committees & $\begin{array}{c}.08^{*} \\
(.03)\end{array}$ & $\begin{array}{l}.07^{*} \\
(.03)\end{array}$ & $\begin{array}{l}.15^{*} \\
(.04)\end{array}$ \\
\hline \# Policy Areas for Agency & $\begin{array}{l}.02 \\
(.01)\end{array}$ & & \\
\hline Bush Agenda? & $\begin{array}{l}.04 \\
(.07)\end{array}$ & & \\
\hline Agency Ideal Point & $\begin{aligned}-.12^{*} \\
(.03)\end{aligned}$ & & \\
\hline Independent Commission? & $\begin{aligned}-.91^{*} \\
(.16)\end{aligned}$ & & \\
\hline Cabinet Department? & $\begin{aligned}-.22^{*} \\
(.11)\end{aligned}$ & & \\
\hline Bureaucrats' Ideal Point & $\begin{aligned}-.08^{*} \\
(.04)\end{aligned}$ & $\begin{array}{r}-.07^{*} \\
(.04)\end{array}$ & $\begin{array}{l}-.09 \\
(.06)\end{array}$ \\
\hline Appointee Indicator & $\begin{array}{c}-.05 \\
(.10)\end{array}$ & $\begin{array}{l}-.01 \\
(.09)\end{array}$ & $\begin{array}{l}-.03 \\
(.17)\end{array}$ \\
\hline Employed in Field Office? & $\begin{array}{l}-.02 \\
(.06)\end{array}$ & $\begin{array}{l}.07 \\
(.08)\end{array}$ & $\begin{array}{l}.004 \\
(.13)\end{array}$ \\
\hline Years Employed in Agency & $\begin{aligned}-.002 \\
(.002)\end{aligned}$ & $\begin{aligned}-.001 \\
(.002)\end{aligned}$ & $\begin{array}{r}-.001 \\
(.004)\end{array}$ \\
\hline Executive Pay Grade & $\begin{array}{c}-.002 \\
(.01)\end{array}$ & $\begin{array}{l}.008 \\
(.01)\end{array}$ & $\begin{array}{l}.01 \\
(.02)\end{array}$ \\
\hline $\mathrm{R}^{2}$ & .09 & .13 & .05 (pseudo) \\
\hline $\mathrm{N}$ & 1509 & 1670 & 1670 \\
\hline
\end{tabular}

Note: *denotes two-tailed significance at .10 or better. Standard errors are clustered by agency in Models 5 and 6.

We estimate the relationship within an agency controlling for several characteristics of the surveyed executives. We control for the executives' ideal point on salient political issues to control for the possibility that individual policy preferences affect the level of perceived presidential influence (Clinton et al. 2012). To control for differences in either actual or perceived influence, we also include whether the respondent is a political appointee (Appointee Indicator), whether the respondent works in a field office rather than in Washington, DC (Employed in Field Office?), the number of years the respondent has been employed in the federal bureaucracy (Years Employed in Agency), and the respondent's pay grade (Executive Pay Grade). ${ }^{11}$ The critical variable for the analysis, however, is the number of committees exercising active oversight

\footnotetext{
${ }^{11}$ This would occur if, for example, liberal executives were either more likely to be targeted for presidential activity or else more likely
}

according to the respondent (\# Oversight Committees). Table 3 reports the relationship. ${ }^{12}$

Table 3 reveals that for any sensible assumption about the error structure of the data-generating process, the substantive relationship between committee involvement and congressional influence is identical.

As in the third section, the influence of the president relative to Congress increases as the number of committees exercising active oversight increases. Increasing the number of committees from " $1-2$ " to " $3-4$," for example, increases relative perceived presidential influence by

to perceive attempted influence by the president, or if lower-level executives (either in terms of pay or time served) or executives in field offices perceived interactions differently than others.

\footnotetext{
${ }^{12}$ The cut points for the ordered logit are nearly uniformly distributed-6.5, -4.2, - 2.5, - .87, 1.4, 3.3, 5.3, 6.7-suggesting that the nature of the dependent variable is likely not an issue.
} 
between 0.07 and 0.09 . In terms of the substantive impact, this change is about one-tenth of a standard deviation. Moving from no committees exercising active oversight to " $9+$ " committees results in a net change of roughly one-half a standard-deviation change in relative influence.

The relationship between the relative presidential influence and the number of involved committees is stronger across agencies than within agencies, but in either case we find that the greater the number of committees that are involved in the oversight of the agency (or program within the agency), the more influential the president is for agency policymaking relative to the congressional committees.

\section{Examining Possible Reasons for the Relationship}

Given the strong correlation between the number of involved congressional committees and relative presidential influence among and within agencies in the $110^{\text {th }}$ Congress we document, which of the many possible reasons sketched in the first section are most likely responsible? One possibility is that as the number of committees involved in overseeing an agency increases, policy disagreements among the involved committees become more likely. Alternatively, more committee involvement may result in less influence even if committees agree because of collective action problems and increased transaction costs.

Disentangling these two possible explanations is difficult given the available data. Doing so requires identifying which committees exercise oversight and locating the policy preferences of these committees relative to one another and to the agencies themselves in order to measure preference divergence. Moreover, even if these challenges are overcome, the data may be uninformative as to which aspect is most responsible for the relationship because the explanations are not mutually exclusiveCongress may simultaneously encounter both preference divergence among committees and increased transaction costs.

Our survey provides some ability to measure the required concepts. To identify the committees involved in agency oversight, we use the responses of career executives to two open-ended questions that asked for the name of the committee in the House and the Senate whose jurisdiction overlaps most with the work of the respondent's agency or program. We measure committee involvement using every committee mentioned in ei- ther the House or the Senate. ${ }^{13}$ The number of unique committees named by career executives within an agency varies from 3 (NLRB) to 21 (USDA). We are able to use the open-ended responses for 30 agencies due to confidentiality agreements, and respondents in these agencies named 11 different committees on average. ${ }^{14}$ Not surprisingly, the Appropriations Committee was the most frequently mentioned committee in each chamber-it constituted $22 \%$ of the mentions in the House (408/1866) and 20\% of the mentions in the Senate (361/1847).

Using the list of committees named for each agency, we then identify the ideal point for the median member in each committee for each agency based on the roll calls from the $110^{\text {th }}$ Congress using the estimator of Clinton, Jackman, and Rivers (2004). Using the executives' ideal points based on the 14 issues that were voted upon in the $109^{\text {th }}$ Congress (Clinton et al. 2012), we locate the average ideal point of the careerists in the agency relative to the committee median. ${ }^{15}$

Figure 2 graphs the preference configuration for the 30 agencies and bureaus with more than 10 respondents. The figure plots the preferences of the average careerist in an agency (with 95\% credible regions), the median committee member for every committee named by an agency member, and the median members of the chambers and majority parties. Agencies are ordered from the most liberal (bottom) to the most conservative (top), and the light-gray shaded area denotes agencies located between the Democratic-controlled House and Senate chamber medians. The number of circles reflects the number of named committees relevant for each agency, and the labeled vertical lines denote the location of median House and Senate Democrats as well as the House and Senate medians. President Bush's ideal point is omitted because it is more conservative than any of the agencies and committee medians (his ideal point is 1.25 ). ${ }^{16}$ For context, the

\footnotetext{
${ }^{13}$ Some respondents provided more than one committee (some named up to five). One limitation is that this question is not necessarily equivalent to the question we analyze in the third section.

${ }^{14}$ Confidentiality requirements limit us to agencies and bureaus with more than 10 respondents. ${ }^{15}$ One complication is that the issues were considered in the $109^{\text {th }}$
Congress, but the questions about oversight involve the $110^{\text {th }}$
Congress. To use the estimates from the $109^{\text {th }}$ Congress to gen-
erate estimates for the $110^{\text {th }}$ Congress, we jointly analyze the voting
behavior of the $109^{\text {th }}$ Congress and $110^{\text {th }}$ Congress, holding the
ideal points of members serving in both congresses constant to
fix the scale of the recovered ideal points. We regress the agency-
comparable ideal points of Clinton et al. $(2012)$ on these ideal
points for those members who serve in the $109^{\text {th }}$ Congress and
use the resulting relationship to generate ideal points for members
newly elected in the $110^{\text {th }}$ Congress.
}

${ }^{16}$ Figure A5 in the appendix presents the full distribution of congressional ideal points. 


\section{FIgURE 2 Policy Preferences of Agencies and the Committees} Identified as Exercising Oversight over the Agency in the $110^{\text {th }}$ Congress

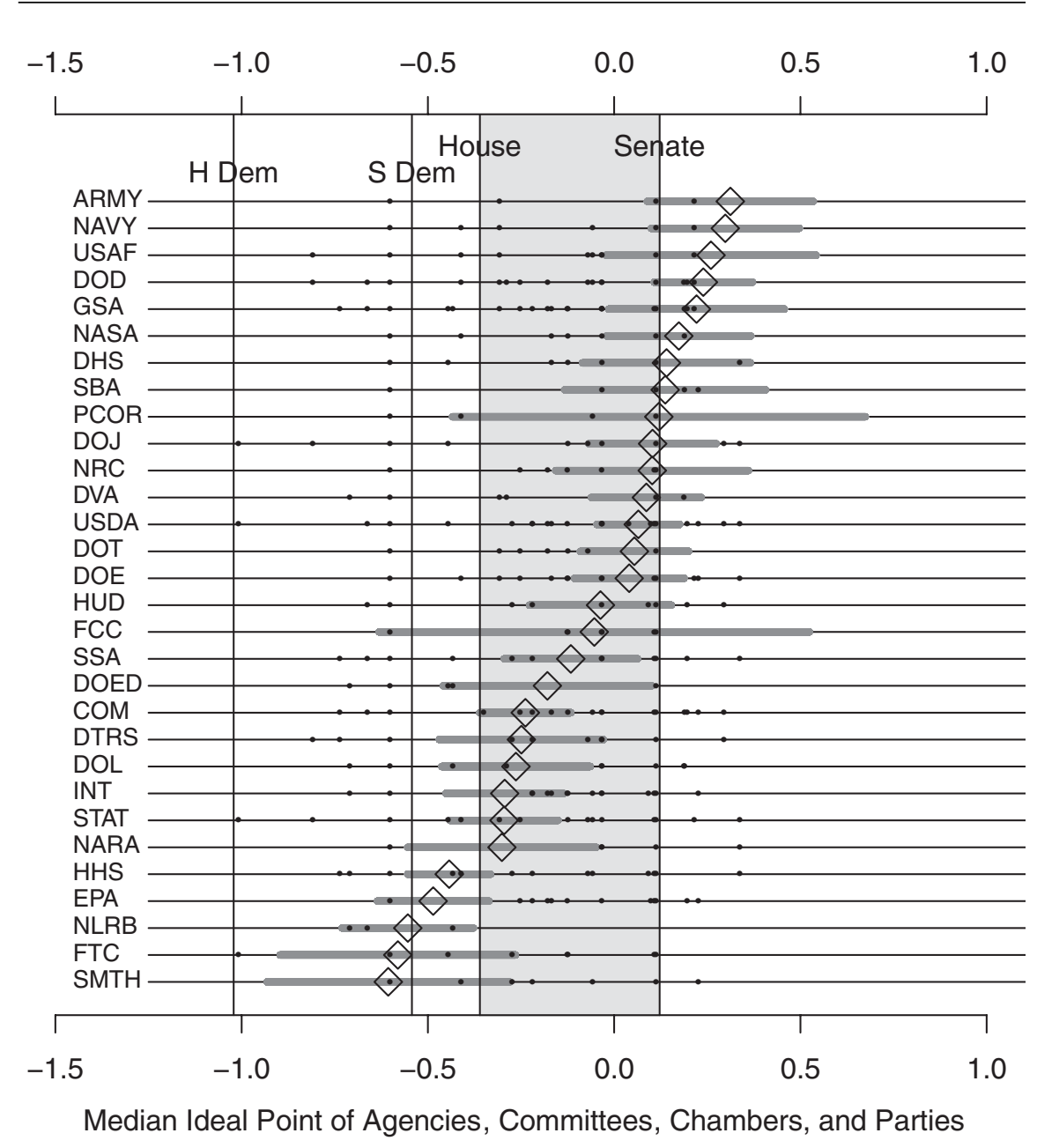

Note: Only agencies with at least 10 respondents are graphed. Ideal points are based on the estimates from Clinton et al. (2012). Vertical lines denote the ideal points of the (from left to right) House Democratic median, Senate Democratic median, House median, and Senate median.

most liberal committee in Figure 2 is the House Judiciary committee, and the most conservative committee is the House Homeland Security committee.

Every agency except for one has multiple committee medians to the left of the agency's ideal point; 25 out of the 30 agencies have at least one committee on either side of their ideal point; and 17 agencies lie between the predicted location of the House and Senate median members. Figure 2 reveals there is almost always at least one committee (and often a chamber) that would oppose an attempt to move agency policy in either ideological direction in the $110^{\text {th }}$ Congress for these agencies.

The configuration of preferences in Figure 2 may suggest why Congress would have difficulty in responding to presidential influence, but the configuration also makes it impossible to determine whether the relationships of the third and fourth sections are primarily due to preference divergence among the committees overseeing the agency or transaction costs and coordination problems because of the number of committees involved in oversight because both aspects are present in nearly every case. Although necessarily speculative because the observations identifying the effect are rather weak, regressions controlling for the number of committees involved and the dispersion in the committee preferences using several measures (e.g., the range, the standard deviation) cannot reject the null that the ideological dispersion of the committee medians has no influence on the relative influence of Congress. In contrast, the number of involved committees continues to have a strong positive correlation with 
increased presidential influence over agency policymaking in these regressions.

\section{Conclusion and Implications}

Answering "who controls the policymaking in the bureaucracy?" has broad implications for governance and democratic accountability. Despite the importance of the question, however, it is a question that is notoriously difficult to answer. Our survey of federal executives provides an opportunity to break this logjam. Focusing on the variation among and within agencies in the $110^{\text {th }}$ Congress (2007-2009), we offer some important conclusions about the relative ability of Congress and the president to influence agency policymaking.

We demonstrate that there is a strong relationship between the number of committees involved in oversight and the lack of congressional influence relative to the White House. This relationship is evident both among agencies and the bureaus within agencies. Based on the perceptions and opinions of those individuals most responsible for implementing agency policy, the more congressional committees involved in the oversight of an agency, the weaker Congress is relative to the president. This suggests that the more Congress cares about an issue-at least as reflected in the structure of its committee system - the less influence Congress may have over the direction of agency policymaking. A troubling tension may therefore exist between the institutions that maximize members' electoral benefits and constituency responsiveness and those that maximize congressional influence over policy outcomes.

To be clear, our results do not suggest that Congress is ineffectual in influencing agency policy. Nor do they call into question prior findings that electorally minded members of Congress are able to influence the spending decisions of agencies. Instead, our results relate to the net effect of the interplay of presidential and congressional influence over the totality of agency policymaking (consisting of both the provision of private goods affecting particular localities and public goods concerning matters of general policy). Even if the committee system is optimally designed to allow members of Congress to respond to the demands of their constituents and claim credit for the goings-on of the federal bureaucracy, this does not necessarily translate into an ability (or willingness) to influence agency policy overall.

Interpreting our results alongside the existing literature suggests that increasing the number of committees with access to an agency may simultaneously increase the ability of members to secure electorally valuable private goods for their constituents but undermine the ability of Congress as an institution to respond collectively to the actions of the presidency or the bureaucracy. For example, the 108 committees and subcommittees overseeing the Department of Homeland Security may provide members with access to DHS resources but also affect the ability of Congress to compete with presidential influence over the general direction of agency policy. Members overly focused on securing district resources such as homeland security grants, visas for constituents, and disaster relief from the department may be unwilling or unable to focus on the larger policy goals. The ability and incentive of members of Congress to secure private goods for their district does not imply that a similar ability and incentive exists when dealing with the provision of public goods and the more diffuse policy goals.

Congress is not unaware of the predicament it confronts when trying to oversee and influence the executive branch. The Joint Committee on the Organization of Congress in the $103^{\text {rd }}$ Congress (1993-94), for example, weighed several different options of jurisdictional reform to eliminate policy overlaps, including a proposal to correspond committee jurisdiction with executive branch structure. While acknowledging that such a committee system could improve the relationship between Congress and the bureaucracy and might help facilitate more comprehensive oversight of the executive branch, the Joint Committee ultimately decided against a reorganization, and it reached the curious conclusion that "the Executive Branch is not optimally organized, making executive reorganization a desirable precursor to this arrangement" (U.S. Congress 1993, S. Prt. 103-55, 793). As was the case when the Department of Homeland Security was established, despite recognizing the potential difficulties for effective congressional oversight and influence (and, having to survey career executives to try to figure out which of its committees was interacting with the various executive agencies!), Congress intentionally decided against reorganizing the system of congressional oversight.

Given the role played by the unelected bureaucracy in implementing policy, examining the ability of the elected branches to influence agency behavior is critically important. We find that the structure of the committee system leads to potential problems for congressional influence relative to the executive. Combined with the fact that members have little incentive to change a system that works for them (Adler 2002), the prospects for congressional control over the direction of agency policy seem remote in some areas. To the extent that the bureaucracy is responsive to elected officials when implementing policy, the structure and incentives present suggest a strong bias in favor of the president relative to Congress. 


\section{References}

Aberbach, Joel D. 1990. Keeping a Watchful Eye. Washington, DC: Brookings.

Aberbach, Joel D., and Bert A. Rockman. 2000. In the Web of Politics. Washington, DC: Brookings.

Adler, E. Scott. 2002. Why Congressional Reforms Fail: Reelection and the House Committee System. Chicago: University of Chicago Press.

Aldrich, John H. 1995. Why Parties? Chicago: University of Chicago Press.

Arnold, R. Douglas. 1980. Congress and the Bureaucracy: A Theory of Influence. New Haven, CT: Yale University Press.

Balla, Steven J. 2000. "Legislative Organization and Congressional Review of Agency Regulations." Journal of Law, Economics, and Organization 16(2): 424-48.

Banks, Jeffrey S., and Barry R. Weingast. 1992. "The Political Control of Bureaucracies under Asymmetric Information." American Journal of Political Science 36(2): 509-24.

Baumgartner, Frank R., and Bryan D. Jones. 1993. Agendas and Instability in American Politics. Chicago: University of Chicago Press.

Baumgartner, Frank R., Bryan D. Jones, and Michael C. MacLeod. 2000. "The Evolution of Legislative Jurisdictions." Journal of Politics 62(2): 321-49.

Bawn, Kathleen. 1995. "Political Control versus Expertise: Congressional Choices about Administrative Procedures." American Political Science Review 89(1): 62-73.

Bendor, Jonathan B. 1985. Parallel Systems: Redundancy in Government. Berkeley: University of California Press.

Bertelli, Anthony M., and Christian R. Grose. 2009. "Secretaries of Pork? Executive Ideology, Multiple Bureaucratic Principals, and Distributive Public Policy." Journal of Politics 71(3): 926-45.

Calvert, Randall L., Mathew McCubbins, and Barry R. Weingast. 1989. "A Theory of Political Control and Agency Discretion." American Journal of Political Science 33(3): 588-611.

Clinton, Joshua D., Anthony Bertelli, Christian Grose, David E. Lewis, and David C. Nixon. 2012. "Separated Powers in the United States: The Ideology of Agencies, Presidents and Congress." American Journal of Political Science 56(2): 34154.

Clinton, Joshua D., Simon Jackman, and Douglas Rivers. 2004. "The Statistical Analysis of Roll Call Data." American Political Science Review 98: 355-70.

Clinton, Joshua D., and David E. Lewis. 2008. "Expert Opinion, Agency Characteristics, and Agency Preferences." Political Analysis 16(1): 3-20.

Cohen, Dara Kay, Mariano-Florentino Cuellar, and Barry R. Weingast. 2006. "Crisis Bureaucracy: Homeland Security and the Political Design of Legal Mandates." Stanford Law Review 59(3): 673-759.

Dahl, Robert A., and Charles E. Lindblom. 1953. Politics, Economics, and Welfare. New York: Harper and Brothers.

Dodd, Lawrence C., and Richard L. Schott. 1979. Congress and the Administrative State. New York: Wiley.
Evans, C. Lawrence. 1999. "Legislative Structure: Rules, Precedents, and Jurisdictions." Legislative Studies Quarterly 24(4): 605-42.

Evans, C. Lawrence. 2005. "Politics of Congressional Reform." In The Legislative Branch, ed. Paul J. Quirk and Sarah A. Binder. New York: Oxford University Press, 490-524.

Fenno, Richard F. 1973. Congressmen in Committees. Boston: Little, Brown.

Ferejohn, John, and Charles Shipan. 1990. "Congressional Influence on Bureaucracy." Journal of Law, Economics, and Organization 6: 1-20.

Fiorina, Morris P. 1977. Congress: Keystone of the Washington Establishment. New Haven, CT: Yale University Press.

Fishel, Jeff. 1985. Presidents and Promises. Washington, DC: CQ Press.

Gailmard, Sean. 2009. "Multiple Principals and Oversight of Bureaucratic Policy-Making." Journal of Theoretical Politics 21(2): 161-86.

Golden, Marissa Martino. 2000. What Motivates Bureaucrats? New York: Columbia University Press.

Hall, Richard L. 1996. Participation in Congress. New Haven, CT: Yale University Press.

Hall, Richard L., and Kristina C. Miler. 2008. "What Happens after the Alarm? Interest Group Subsidies to Legislative Overseers." Journal of Politics 70(4): 990-1005.

Hammond, Thomas H., and Jack H. Knott. 1996. "Who Controls the Bureaucracy? Presidential Power, Congressional Dominance, Legal Constraints, and Bureaucratic Autonomy in a Model of Multi-Institutional Policy-Making." Journal of Law, Economics, and Organization 12(1): 119-66.

Hammond, Thomas H., and Jack H. Knott. 1999. "Political Institutions, Public Management, and Policy Choice." Journal of Public Administration Research and Theory 9(January): 33-85.

Hebert, F. Ted, Jeffrey L. Brudney, and Deil S. Wright. 1983. "Gubernatorial Influence and State Bureaucracy." American Politics Quarterly 11(2): 243-64.

Kaniewski, Daniel J. 2010. "Congress Should Consider Its Own Failures in Attempted Bombing." Roll Call, February 19. http://www.rollcall.com/news/43351-1.html (Accessed December 29, 2010).

King, David C. 1997. Turf Wars: How Congressional Committees Claim Jurisdiction. Chicago: University of Chicago Press.

Laffont, Jean-Jacques, and Jean Tirole. 1993. A Theory of Incentives in Procurement and Regulation. Cambridge, MA: MIT Press.

Landau, Martin. 1969. "Redundancy, Rationality, and the Problem of Duplication and Overlap." Public Administration Review 29(4): 346-58.

MacDonald, Jason A. 2007. "Agency Design and Postlegislative Influence over the Bureaucracy." Political Research Quarterly 60(4): 683-95.

Mann, Thomas, and Norman Ornstein. 2006. "When Congress Checks Out.” Foreign Affairs November/December: 67-82.

Maranto, Robert. 1993a. "Still Clashing after All These Years: Ideological Conflict in the Reagan Executive." American Journal of Political Science 37(3): 681-98. 
Maranto, Robert. 1993b. Politics and Bureaucracy in the Modern Presidency. Westport, CT: Greenwood.

Maranto, Robert. 2005. Beyond a Government of Strangers. Lanham, MD: Lexington Press.

Maranto, Robert, and Karen M. Hult. 2004. "Right Turn? Political Ideology in the Higher Civil Service, 1987-1994." American Review of Public Administration 34: 199-222.

Mayhew, David. 1974. Congress: The Electoral Connection. New Haven, CT: Yale University Press.

McCubbins, Mathew D., Roger G. Noll, and Barry R. Weingast. 1987. "Administrative Procedures as Instruments of Political Control." Journal of Law, Economics, and Organization 3(2): 243-77.

McCubbins, Mathew D., Roger G. Noll, and Barry R. Weingast. 1989. "Structure and Process, Politics and Policy: Administrative Arrangements and the Political Control of Agencies." Virginia Law Review 75: 431-82.

McCubbins, Matthew D., and Thomas Schwartz. 1984. "Congressional Oversight Overlooked: Police Patrol versus Fire Alarm." American Journal of Political Science 28(1): 165-77.

Meier, Kenneth John, and Lloyd G. Nigro. 1976. "Representative Bureaucracy and Policy Preferences: A Study in the Attitudes of Federal Executives." Public Administration Review 36(4): 458-69.

Miller, Gary J. 2005. “The Political Evolution of Principal-Agent Models." Annual Review of Political Science 8: 203-25.

Miller, Gary J., and Thomas H. Hammond. 1990. "Committees and the Core of the Constitution." Public Choice 66(2): 101-16.

Moe, Terry M. 1984. "The New Economics of Organization.” American Journal of Political Science 28(4): 739-77.

Moe, Terry M. 1985. "Control and Feedback in Economic Regulation: The Case of the NLRB." American Political Science Review 79(4): 1094-1116.

Moe, Terry M. 1987. "An Assessment of the Positive Theory of 'Congressional Dominance'.” Legislative Studies Quarterly 12(4): 475-520.

National Commission on Terrorist Attacks upon the United States. 2004. The 9/11 Commission Report. Washington, DC: Government Printing Office.

O’Connell, Anne Joseph. 2006. “The Architecture of Smart Intelligence: Structuring and Overseeing Agencies in the Post9/11 World." California Law Review 94: 1655-1744.

Ogul, Morris S., and Bert A. Rockman. 1990. "Overseeing Oversight: New Departures and Old Problems." Legislative Studies Quarterly 15(1): 5-24.

Scholz, John T., and B. Dan Wood. 1998. "Controlling the IRS: Principals, Principles, and Public Administration." American Journal of Political Science 42(1): 141-62.

Seidman, Harold. 1998. Politics, Position, and Power: The Dynamics of Federal Organization. 5th ed. New York: Oxford University Press.
Shepsle, Kenneth A. 1978. The Giant Jigsaw Puzzle: Democratic Committee Assignments in the Modern House. Chicago: University of Chicago Press.

Snyder, Susan K., and Barry R. Weingast. 2000. "American System of Shared Powers: The President, Congress, and the NLRB." Journal of Law, Economics, and Organization 16(2): 269-305.

Steunenberg, Bernard. 1992. "Congress, the Bureaucracy, and Regulatory Policy-Making." Journal of Law, Economics, and Organization 8(3): 673-94.

Talbert, Jeffery C., Bryan D. Jones, and Frank R. Baumgartner. 1995. "Nonlegislative Hearings and Policy Change in Congress." American Journal of Political Science 39(2): 383405.

U.S. Congress. Joint Committee on the Organization of Congress. 1993. Background Materials: Supplemental Information Provided to Members of the Joint Committee on the Organization of Congress. $103^{\text {rd }}$ Congress, $1^{\text {st }}$ Session. S. Prt. 103-55.

Weingast, Barry R. 1984. “The Congressional-Bureaucratic System: A Principal Agent Perspective (with Applications to the SEC)." Public Choice 44: 147-91.

Weingast, Barry R., and Mark J. Moran. 1983. "Bureaucratic Discretion or Congressional Control? Regulatory PolicyMaking by the Federal Trade Commission." Journal of Political Economy 91(5): 765-800.

Whitford, Andrew B. 2005. "The Pursuit of Political Control by Multiple Principals." Journal of Politics 67(1): 29-49.

Wilson, James Q. 1989. Bureaucracy: What Government Agencies Do and Why They Do It. New York: Basic Books.

Wood, B. Dan, and James E. Anderson. 1993. "The Politics of U.S. Antitrust Regulation." American Journal of Political Science 37(1): 1-39.

Wood, B. Dan, and Richard Waterman. 1993. "The Dynamics of Political-Bureaucratic Adaptation." American Journal of Political Science 37(2): 497-528.

Woolley, John T. 1993. "Conflict among Regulators and the Hypothesis of Congressional Dominance." Journal of Politics 55(1): 92-114.

\section{Supporting Information}

Additional Supporting Information may be found in the online version of this article at the publisher's website:

Appendix A: Descriptive Statistics and Additional Specifications

Appendix B: Details of the Survey on the Future of Government Service 